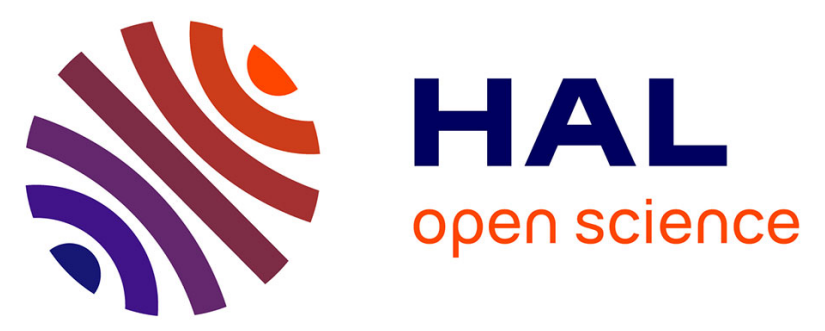

\title{
Development of set of SNP markers for population genetics studies of lpe (Handroanthus sp.), a valuable tree genus from Latin America
}

Barbara R. V. Meyer-Sand, Celine Blanc-Jolivet, Malte Mader, Kathelyn Paredes-Villanueva, Niklas Tysklind, M. Sebben Alexandre, Erwan Guichoux, Bernd Degen

\section{To cite this version:}

Barbara R. V. Meyer-Sand, Celine Blanc-Jolivet, Malte Mader, Kathelyn Paredes-Villanueva, Niklas Tysklind, et al.. Development of set of SNP markers for population genetics studies of lpe (Handroanthus sp.), a valuable tree genus from Latin America. Conservation Genetics Resources, 2018, 10 (4), pp.779-781. 10.1007/s12686-017-0928-5 . hal-02196135

\section{HAL Id: hal-02196135 \\ https://hal.science/hal-02196135}

Submitted on 26 Jul 2019

HAL is a multi-disciplinary open access archive for the deposit and dissemination of scientific research documents, whether they are published or not. The documents may come from teaching and research institutions in France or abroad, or from public or private research centers.
L'archive ouverte pluridisciplinaire $\mathbf{H A L}$, est destinée au dépôt et à la diffusion de documents scientifiques de niveau recherche, publiés ou non, émanant des établissements d'enseignement et de recherche français ou étrangers, des laboratoires publics ou privés. 


\title{
Development of a set of SNP markers for population genetics studies of Ipe (Handroanthus sp.), a valuable tree genus from Latin America
}

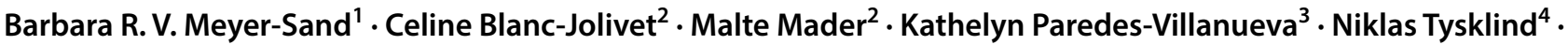 \\ Alexandre M. Sebbenn ${ }^{5} \cdot$ Erwan Guichoux $^{6} \cdot$ Bernd Degen $^{2}$
}

Received: 9 November 2017 / Accepted: 16 November 2017

(c) Springer Science+Business Media B.V., part of Springer Nature 2017

\begin{abstract}
A combination of restriction associated DNA sequencing (RADSeq) and low coverage MiSeq genome sequencing was used for the development of single nucleotide polymorphisms (SNP) and INDEL (insertion/deletions) genetic markers for Ipe (Handroanthus sp.). Of the 402 putative loci identified, 389 SNPs and INDELs (315 nuclear SPNs, six chloroplast INDELs, 15 chloroplast SNPs, 12 mitochondrial INDELs and 41 mitochondrial SNPs) were successfully genotyped at 93 individuals from Brazil, Bolivia and French Guiana using a MassARRAY ${ }^{\circledR}$ iPLEX ${ }^{\mathrm{TM}}$ platform. This set of markers will be invaluable for population genetics, phylogeography and DNA fingerprinting studies.
\end{abstract}

Keywords Handroanthus sp. $\cdot$ Single nucleotide polymorphism $\cdot$ MassARRAY

\section{Introduction}

Electronic supplementary material The online version of this article (https://doi.org/10.1007/s12686-017-0928-5) contains supplementary material, which is available to authorized users.

Celine Blanc-Jolivet

celine.blanc-jolivet@thuenen.de

1 Departamento de Fitotecnia, Tecnologia de Alimentos e Sócio Economia, Faculdade de Engenharia de Ilha Solteira, Universidade Estadual Paulista, Ilha Solteira, SP, Brazil

2 Thünen Institute of Forest Genetics, Sieker Landstrasse 2, 22927 Grosshansdorf, Germany

3 Carrera de Ingeniería Forestal, Laboratorio de Dendrocronología, Facultad de Ciencias Agrícolas, Universidad Autónoma Gabriel René Moreno, Km 6 carretera al Norte, El Vallecito, Santa Cruz, Bolivia

4 INRA, UMR0745 EcoFoG, AgroParisTech, Cirad, CNRS, Université des Antilles, Université de Guyane, Campus Agronomique, Avenue de France, BP97387 Kourou Cedex, France

5 Instituto Florestal de São Paulo, CP 1322, São Paulo, SP 01059-970, Brazil

6 Plateforme Génome Transcriptome de Bordeaux, INRA Pierroton, Bâtiment Artiga, 69 route d'Arcachon, 33610 Cestas, France
The genus Handroanthus comprises 30 tree species, belongs to the botanical family Bignoniacaea and presents one of the most valuable timber from South America, which is threatened because of its overexploitation (Schulze et al. 2008). This genus has a complex and long taxonomic history due to its anatomical and morphological variety. Grose and Olmstead (2007) reclassified part of the Tabebuia species under the Handroanthus genus, as a result of molecular and phylogenetic studies using sequences of the chloroplast regions trnL-F and ndhF. Of the 21 microsatellite loci developed for Tabebuia aurea, nine loci were successfully amplified in four other Handroanthus species (Braga et al. 2007). However, the amplification and scoring of microsatellite loci from timber material is problematic due to the low quality and quantity of DNA which can be recovered, which motived the development of SNP markers for timber tracking purposes in other economically important tropical species (Blanc-Jolivet et al. 2017a, b; Jardine et al. 2016; Pakull et al. 2016). Here we therefore describe a set of SNP markers for genetic studies in Handroanthus sp. We present a set of $101 \mathrm{SNP} /$ Indel markers which were analyzed using MassARRAY $^{\circledR}{ }^{\circledR}$ iPLEX $^{\mathrm{TM}}$ genotyping (Agena Bioscience, Hamburg, Germany), which can be used for effective analysis of molecular population structure within the genus. 


\section{Materials and methods}

\section{Marker development and marker screening}

Dried Handroanthus sp. tissue material (leaf, cambium or bark) were collected from 28 trees in Bolivia, 50 trees in Brazil and 15 trees in French Guiana, totalling 93 individuals (Table 1). DNA was isolated from leaf, cambium or bark according to Dumolin et al. (1995), either at the Thünen Institute (Germany) or at the São Paulo State University (UNESP). Among the collected individual samples, five individuals confidently identified as $H$. serratifolius were selected for SNP/INDELs locus identification (Table 2). Restriction associated DNA sequencing (RADseq) was used for nuclear SNPs (nSNPs) discovery (Miller et al. 2007) and low coverage MiSeq genome sequencing was conducted for the detection of chloroplast and mitochondrial SNPs (cpSNPs and mtSNPs) and INDELs (Straub et al. 2012). The suitability of all identified genetic makers for a MassARRAY ${ }^{\circledR}$ iPLEX $^{\mathrm{TM}}$ design (Assay Design Suite v2.0 [Agena Bioscience ${ }^{\mathrm{TM}}$, San Diego, USA]) was evaluated according to sequencing data quality and different allele distribution patterns among the five individuals. Once a set of SNPs/INDELs markers was identified, genotyping of all individuals was conducted using the MassARRAY ${ }^{\circledR}$ iPLEX $^{\mathrm{TM}}$ platform (Agena Bioscience ${ }^{\mathrm{TM}}$, San Diego, USA) and the iPLEX ${ }^{\mathrm{TM}}$ GOLD chemistry (Table 1). Allele calling was processed with Typer Viewer v.4.0.24.71 (Agena Bioscience $^{\mathrm{TM}}$, San Diego, USA).
Table 1 Country, species, number of individuals $(n)$ and geographic coordinates of individuals used for the initial SNP selection on the MassARRAY ${ }^{\circledR}$ iPLEX $^{\mathrm{TM}}$ platform (Agena Bioscience ${ }^{\mathrm{TM}}$ )

\begin{tabular}{|c|c|c|c|c|c|}
\hline Country & Location & Species & $n$ & Latitude & Longitude \\
\hline Bolivia & Bajo Paraguá & H. serratifolius & 1 & -15.4182 & -61.4443 \\
\hline Bolivia & Bajo Paraguá & Handroanthus sp. & 2 & -16.2612 & -61.0780 \\
\hline Bolivia & Bajo Paraguá & H. impetiginosus & 2 & -16.2564 & -61.0724 \\
\hline Bolivia & Concepción & H. impetiginosus & 5 & -16.1674 & -61.7679 \\
\hline Bolivia & Guarayos & Handroanthus sp. & 2 & -15.5183 & -63.1966 \\
\hline Bolivia & Guarayos & H. serratifolius & 3 & -15.5125 & -63.1974 \\
\hline Bolivia & Roboré & Handroanthus sp. & 1 & -18.3275 & -59.5904 \\
\hline Bolivia & Roboré & H. impetiginosus & 4 & -18.4522 & -59.4169 \\
\hline Bolivia & Rurrenabaque, El Paraiso & Handroanthus sp. & 1 & -14.5667 & -67.3033 \\
\hline Bolivia & Yapacaní, Naranjal & H. serratifolius & 7 & -17.4293 & -63.9151 \\
\hline Brazil & FLONA do Jamari & H. incanus & 5 & -9.3965 & -62.9226 \\
\hline Brazil & FLONA do Jamari & H. impetiginosus & 5 & -9.3985 & -62.9248 \\
\hline Brazil & FLONA Amapá & Handroanthus sp. & 6 & 0.8668 & -51.6012 \\
\hline Brazil & FLONA de Tapajós & H. serratifolius & 8 & -2.8641 & -54.9269 \\
\hline Brazil & FLONA do Carajás & Handroanthus sp. & 13 & -6.1971 & -49.0848 \\
\hline Brazil & RESEX Chico Mendes & Handroanthus sp. & 3 & -10.7751 & -69.6563 \\
\hline Brazil & RESEX Tapajós - Arapins & Handroanthus sp. & 5 & -3.0783 & -55.2841 \\
\hline Brazil & Piracicaba, Brazil & H. rosea albus & 1 & -22.725 & -47.6476 \\
\hline Brazil & Piracicaba, Brazil & H. ochraceus & 1 & -22.725 & -47.6476 \\
\hline Brazil & Piracicaba, Brazil & H. heptaphyllus & 1 & -22.725 & -47.6476 \\
\hline Brazil & Piracicaba, Brazil & H. chrysotrichus & 1 & -22.725 & -47.6476 \\
\hline Brazil & Piracicaba, Brazil & H. impetiginosus & 1 & -22.725 & -47.6476 \\
\hline French Guiana & Belizon & Handroanthus sp. & 5 & 4.2089 & -52.5480 \\
\hline French Guiana & Paracou & H. serratifolius & 2 & 5.2601 & -52.9361 \\
\hline French Guiana & Kourou-Cayenne & H. serratifolius & 8 & 5.0020 & -52.4808 \\
\hline
\end{tabular}

Table 2 Location and number of individuals used for SNP discovery from both RADseq and MiSeq sequencing approaches

\begin{tabular}{llllrr}
\hline Sample code & Sequencing technique & Country & Location & Latitude & Longitude \\
\hline TASER_1 & MiSeq & French Guiana & Paracou & 5.26024 & -52.93566 \\
TASER_2 & RADseq & French Guiana & Paracou & 5.26001 & -52.93647 \\
TASER_40 & MiSeq/RADseq & Bolivia & Yapacaní, Naranjal & -17.43223 & -63.92747 \\
TASER_63 & MiSeq/RADseq & French Guiana & Kourou-Cayenne & 5.06545 & -52.55594 \\
TASER_66 & MiSeq & French Guiana & Kourou-Cayenne & 4.98347 & -52.44759 \\
\hline
\end{tabular}




\section{Statistical analysis}

Amplification rates were determined per locus over all 93 samples. Using the plastidial markers, the total number of haplotypes were estimated per country. H. serratifolius samples were pooled together according to their country of origin for further analysis. Genetic diversity was estimated as the observed $\left(H_{o}\right)$ and expected heterozygosity $\left(H_{e}\right)$ for the nuclear markers. Inbreeding was inferred by the fixation index $\left(F_{I S}\right)$ and its statistical significance was estimated by random permutations of alleles among individuals and using a Bonferroni correction $(\alpha=0.05)$. All analyses were carried out using FSTAT software (Goudet 2002).

\section{Results}

The RADseq and MiSeq sequencing resulted in a set of 402 SNPs/Indels markers (Table S1): 15 cpSNPs, 44 mtSNPs, $325 \mathrm{nSNPs}$, and 12 mitochondrial and six chloroplast INDEL markers. A total of 389 SNPs and INDELs loci could be successfully amplified and scored. The mean amplification rate per locus was $88 \%$ for nSNPs, $95 \%$ for chloroplast and mitochondrial markers among countries and the seven Handroanthus species analysed (Tables S2 and S3). The mean fixation index of nSNPs ranged among countries from 0.008 to 0.678 , indicating a significant homozygote excess (Table S2). Twenty-one haplotypes were detected among Bolivian samples, 46 among Brazilian samples and nine among French Guianese samples.

\section{Conclusion}

The SNPs and INDELs markers presented high amplification and cross-amplification rates. This new SNP marker set will be useful for future studies on genetic diversity and phylogeography within the genus Handroanthus.

Acknowledgements This research was supported by the German Federal Ministry of Food and Agriculture in the frame of the "Large scale project on genetic timber verification". Genotyping was performed at the Genomic and Sequencing Facility of Bordeaux (grants from the Conseil Regional d'Aquitaine Nos 20030304002FA and 20040305003FA, the European Union, FEDER No 2003227 and Investissements d'avenir, Nos ANR-10-EQPX-16-01 and CEBA:
ANR-10-LABX-25-01 to the UMR EcoFoG). We would like to thank the Conselho Nacional de Ciencia e Tecnologia (CAPES) (Mater scholarship at the UNESP/FEIS to B.R.V.M-S), the Chico Mendes Biodiversity Institute (authorizations Nos 47960 and 49369 for sample transportation), FLONA do Jamari, AMATA Company, FLONA Amapá, FLONA de Tapajós, FLONA do Carajás, RESEX Chico Mendes, RESEX Tapajós - Arapins in Brazil, the Museo de Historia Natural Noel Kempff Mercado in Bolivia, as well as the Office National des Forêts in French Guiana for their support in the field.

\section{References}

Blanc-Jolivet C, Kersten B, Bourland N, Guichoux E, Delcamp A, Doucet J-L, Degen B (2017a). Development of nuclear SNP markers for the timber tracking of the African tree species Sapelli, Entandrophragma cylindricum. Conserv Genet Resour. https:// doi.org/10.1007/s12686-017-0872-4

Blanc-Jolivet C, Kersten B, Daïnou K, Hardy O, Guichoux E, Delcamp A, Degen B (2017b) Development of nuclear SNP markers for genetic tracking of Iroko, Milicia excelsa and Milicia regia. Conserv Genet Resour. https://doi.org/10.1007/s12686-017-0716-2

Braga AC, Reis AMM, Leoi LT, Pereira RW, Collevatti RG (2007) Development and characterization of microsatellite markers for the tropical tree species Tabebuia aurea (Bignoniaceae). Mol Ecol Notes 7:53-56

Dumolin S, Demesure B, Pettit R (1995) Inheritance of chloroplast and mitochondrial genomes in pedunculate oak investigated with an efficient PCR method. Theor Appl Genet 91:1253-1256

Goudet J (2002) Fstat (Version 2.9.3.2.): a computer program to calculate $F$-statistics. J Heredity 86:485-486

Grose SO, Olmstead RG (2007) Evolution of a charismatic neotropical clade: molecular phylogeny of Tabebuia s. l. crescentieae, and allied genera (Bignoniaceae). Syst Bot 32:650-659

Jardine DI, Blanc-Jolivet C, Dixon RRM, Dormontt EE, Dunker B, Gerlach J et al (2016) Development of SNP markers for Ayous (Triplochiton scleroxylon K. Schum) an economically important tree species from tropical West and Central Africa. Conserv Genet Resour 8(2):129-139

Miller MR, Dunham JP, Amores A, Cresko WA, Johnson EA (2007) Rapid and cost-effective polymorphism identification and genotyping using restriction site associated DNA (RAD) markers. Genome Res 17:240-248

Pakull B, Mader M, Kersten B, Ekue MRM, Dipelet UGB, Paulini $M$ et al (2016) Development of nuclear, chloroplast and mitochondrial SNP markers for Khaya sp. Conserv Genet Resour 8(3):283-297

Schulze M, Grogan J, Uhl C, Lentini M, Vidal E (2008) Evaluating Ipê (Tabebuia, Bignoniaceae) logging in amazonia: Sustainable management or catalyst for forest degradation? Biol Conserv 141:2071-2085

Straub SC, Parks M, Weitemier K, fishbein M, Cronn RC, Liston A (2012) Navigating the tip of the genomic iceberg: next-generation sequencing for plant systematics. Am J Bot 99:349-364 